\title{
Applying Self-Regulated Learning Intervention to Enhance Students' Learning: A Quasi-Experimental Approach
}

\author{
Astri Dwi Jayanti Suhandoko \\ M.Ed., Ph.D., Universitas Terbuka, Indonesia, astri@ecampus.ut.ac.id \\ Chi-Sui Hsu \\ Prof., National University of Tainan, Taiwan, shuc@mail.nutn.edu.tw
}

This study investigated the effect of intervention associated with self-regulated learning (SRL) to 84 undergraduate students at Universitas Negeri Jakarta (UNJ), Indonesia. The respondents originate from department of primary education (PGSD) who enrolled development of learner's course. This study utilized quasi experimental design support with Motivational Strategies for Learning Questionnaire (MSLQ) as pre-test and post-test instrument. Based on ANCOVA and correlation coefficient result revealed that (1) the undergraduate students who receive self-regulated learning strategies intervention have greater academic performance; (2) there was significantly different between pre-test and post-test result of SRL variables in experimental group; (3) there were correlations among SRL variables on experimental group's post-test result (i.e., academic cognition, academic motivation and academic behavior strategies; and (4) the intervention has an impacted for experimental group regarding their pre-test and post-test result among three variables of SRL.

Keywords: self-regulated learning strategies, quasi experimental, MSLQ, undergraduate students, learning,

\section{INTRODUCTION}

Teachers play a significant and important role in human development (Dar, 2015). They are the ones who are behind the academic achievement and development of student behavior at each stage of learning. This role attempt in accordance with their pedagogical beliefs include how they acknowledged themselves a teacher or a kind of pedagogical methods which they consider is most effective, these two things are likely to influence their interpretation and pedagogical practices that are implemented in the classroom (Ahonen, Pyhältö, Pietarinen, \& Soini, 2014). This belief also influence the way teachers participated in their professional community, such as how teachers collaborate and take a position in curriculum development, and how they utilize the 
expertise of other teachers in developing their own work and school (Ahonen et al., 2014). Therefore, teachers play sentral role in attainment of quality education (Crossley et al., 2017).

In some countries the role of a teacher has a different emphasis adapted to the culture of the society. In Pakistan, the teacher's role is moving away from teacher professional to the model of teacher as a technician which aims to help students to acquire good grades (Dar, 2015). Teachers do excessive development on the cognitive abilities of students at all ages and grade levels. This succeeded in making progress for students in academics but fail to foster affective attitude among them. Whereas in Finland the role of the teacher is expected to help the improvement of the entire individual as opposed to only the human intellectual area. It recognizes the significance of the social and full of feeling spaces in students' improvement, including enthusiastic and moral concerns (Rissanen, Kuusisto, Hanhimäki, \& Tirri, 2018). The different roles and functions of teachers ultimately affect the quality of education in each of these countries, and this is globally motivated by the quality of teacher education institutions.

Teacher education as an integral part of educational system (Prakash \& Xavier, 2014) represented through a college or university is a higher education institution providing education for prospective teachers that imparts an understanding of the role of teachers (Denzler \& Wolter, 2009). According to Crow (1973 cite in Prakash \& Xavier, 2014, p. ) teacher education implies the lifelong development of pedagogical and discipline knowledge, an understanding of learning theory and development, historical and philosophical context of education and the ability to adapting the instructional method with the differences of learning situations. Meanwile Bank (2001 cited in Castro, 2014, p.190) stated that teacher education prepares teachers to meet the challenges of multicultural citizenship, to have a critical attitude to analyze and rethink the idea of race, culture, and ethnicity, and to see themselves as part of the creatures of culture and race. In short, a good quality teacher education would generate excellent prospective teachers.

Responding to the issue of teacher quality, some researchers and scholars who are also a lecturer from a teacher education institution carry out development programs to prospective teachers. One of the programs that concern them is promoting the theory of self-regulated learning (SRL); (Vrieling, Bastiaens, \& Stijnen, 2012; Yakar, Can, \& Besler, 2013). Self-regulated learning becomes a recommended theory should be study because researchers found when students are able to arrange themselves become selfregulated learner, they can develop deep and meaningful learning along significant advantages in student academic performance and achievement (Vrieling et al., 2012)

The requiring of SRL behavior is not only when the prospective teachers was still undergraduate students but also as they will be teachers later. Self-regulation learning is an ongoing process, it assist prospective teachers in assembling the best performance in exploring knowledge and achieving goal (Tantrarungroj \& Suwannatthachote, 2013). On particularly context, SRL assist prospective teachers to learn teaching model based on technology that will be applying the time they teach later (Kramarski \& Michalsky, 2010). At the time when their role turned into a teacher, SRL will helping the 
prospective teacher to transfer this behavior to the students toward teaching program that integrated with SRL theory (Alvi \& Gillies, 2015). It can be concluded that promoting SRL in teacher education institution is one of the ways to produce qualified teachers.

In response to the challenge of SRL strategy development for the prospective teacher, and motivated by study conducted by Hofer and Yu (2003) just as Heller and Marchant (2015), researcher asked permission to the undergraduate students of the Universitas Negeri Jakarta (UNJ) majoring primary education who attend the learners' developmental course to joint quasi-experimental research since March-July 2016. This examination expects to determine the effect of the intervention on variable associated with self-regulated learning strategies for those students. Researcher generated three hypotheses; hypotheses I: undergraduate students who receive self-regulated learning strategies intervention will have greater academic performance, hypotheses II: undergraduate students who receive self-regulated learning strategies intervention will display greater of self-regulated learning, hypotheses III: there are correlated among academic cognition, academic motivation and academic behavior strategies and hypotheses IV: the intervention has an impacted for experimental group regarding their pre-test and post-test result among three variables of SRL.

\section{REVIEW OF LITERATURE}

\section{Self-Regulated Learning}

Since the mid-1980s the concept of self-regulation is the most widely discussed by researchers and scholars who concern of educational psychology. Self-regulation is commonly characterized as the essential capacity of a person which is utilized various logical circumstances conceded as significant part to the advancement of life (Gestsdóttir, Urban, Bowers, Lerner, \& Lerner, 2011). Self-regulation is the manner by which an individual can expand the capacity in apprehend, using and assessing opportunities that exist in the environment so as to accomplish the objectives that they have (Gestsdóttir et al., 2011).

The current researches conducted by educational psychology researchers generate further discussion of the relationship between self-regulation and student achievement (Boekaerts \& Corno, 2005; Zimmerman, 2008). This concept is considered as one of the most important factors that influence the success in learning and academic performance (Bozpolat, 2016). In general self-regulated learning defined as a functioning, useful procedure whereby learner set objectives for their learning and after that endeavor to screen, regulate, and control their cognition, motivation, and behavior, guided and compelled by their objectives and the contextual features in the environment (Pintrich, 2000). Self-regulation learning is a conscious effort made by learners in achieving their learning objectives, its efforts are carried out continuously until they achieve of these objectives with maximizing their self-ability adapted to the environment.

Schunk and Zimmerman (1998) mentioned that self-regulated learning arise from two sources: social and self-directed experiences (Zimmerman, 1998). Social source hold adults (e.g. parents, teachers, coaches) and peers (e.g. siblings, friends, classmates). The constructivist attempts to analyze self-regulated learning, it is important to recognize 
that the strategies, behaviors and affect desirable by students are something that can be regulated because of the existence of others around them (Farley \& Kim-Spoon, 2014; Paris, Byrnes, \& Paris, 2001). The other source that students can develop self-regulated learning is from self-directed experiences sources through instruction (Zimmerman, 1998). Paris \& Paris (2001) noted there are three methods those students to develop self-regulation learning in classroom (Schwartz, 2012). First, self-regulated learning can be developed through authentic experience or repetitive activities in the classroom or school. Second, lecturers can give explicit instructions on self-regulated learning. Third, self-regulated learning can be developed through involvement in the practice of requiring self-regulation (i.e. Practicing classroom discussion).

\section{Self-regulation Learning Strategies}

The instructional model of self-regulated learning that researcher conducted was from two sources, both social and self-directed experience. It's inspired by Hofer, Yu and Pintrich (1998) study that called learning to learn the model. They conducted selfregulated learning strategies intervention that designed for an adjunct course called Learning to Learn. It is an introductory course in psychology departments that attends by sophomore students who experienced academic difficulties and problems. This explicit instructional model has been proven to fostering undergraduate students' skill of learning strategies (Dörrenbächer \& Perels, 2016).

The Self-Regulated Learning strategies are: (1) Cognitive strategies, basically regard as the internal procedures that represent and process information (Lehmann, Hähnlein, \& Ifenthaler, 2014). The instruction model of self-regulated learning that researcher gave are rehearsal (Yusri, Rahimi, Shah, \& Wah, 2013), elaboration (Weinstein, Ridley, Dahl, \& Weber, 1989) and organizational; (2) Meta-cognitive strategies, that refer to superior ability that learners' have to direct and manage cognition, motivation and behavior to achieve certain goals (Lehmann et al., 2014) which include planning (Perels, Merget-Kullmann, Wende, Schmitz, \& Buchbinder, 2009; Pintrich, 2000), monitoring (Boekaerts \& Corno, 2005), management (Boekaerts \& Corno, 2005); (3) Motivational strategy is learners' effort to always search and comprehend the reasons which move them to do something related to strategies in learning process for academic achievement, about how students judge their own competence and value the task content (Pintrich, 2000) such as self-knowledge (Hofer, Yu, \& Pintrich, 1998) and self-efficacy (Paris et al., 2001); (4) Behavioral strategies, at the moment individuals can observe, monitor and control their behavior this is tantamount that they do regulation of behavior as a part of self-regulatory. The strategies are managing the time schedule and do the helpseeking; (5) Contextual strategies, the challenges that must be faced by learners in implementing contextual strategies are the changeable of condition which beyond their control. The example of contextual differences that students need to regulate is when they face different types of classroom or instruction (i.e. Traditional and studentcentered).

\section{Self-regulation Learning Strategies Intervention}

There is various interventions method that can be applied by teachers to develop selfregulation learning on student (Deslauriers, Harris, Lane, \& Wieman, 2012). The 
intervention can be distinguished by its scope, content, and time frame, both in specific and global manner. The scope intervention carried out for this study is global that required a semester period of training, cognitive, meta-cognitive, motivational and behavioral strategies. The provision of this intervention is not only to make students able to master the strategy SRL but also achieve better academic performance (Andrzejewski, Davis, Bruening, \& Poirier, 2016; Gu \& Lee, 2019; Lehmann et al., 2014; Vandevelde, Van Keer, \& De Wever, 2011).

\section{Learning from lecture}

The first session of the intervention where students are required to understand and take advantage of the learning process that goes on with a strategy that their owned, mainly to learn the material provided by the lecturer verbally (e.g. lecture speech) and in textwriting (e.g. PPT slide, white board writing).The strategies that support this session were: (1) note-taking strategies is a way for someone to comprehend (van der Meer, 2012) and reproduce information by write it down, aimed for the information to be stored in long term memory (Piolat, Olive, \& Kellogg, 2005). (2) Conditional reasoning is a strategy used by students at the age capable of doing conditional interpretation (i.e. $9^{\text {th }}$ grade and above) in reasoning (Markovits, Doyon, \& Simoneau, 2002) the statements (i.e. concrete and abstract premises).

\section{Learning from reading}

The second session is to improve the students' skill to comprehend and find the connection of the reading material. The strategy that supported this session was SQ3R (Survey, Question, Read, Recite, Review) as a recommended reading strategy for students to deeply understand what they read (Feldt \& Hensley, 2009). There are correlation between the phase of SQ3R that helps student to understand the material entirely.

\section{Learning from the discussion}

Learning from discussion is the third sessions where students have needed to grasp the discussion process in classroom and to contribute actively with the strategy they have owned. The strategy that supported this session was; the students respectively understand their role in classroom discussion (Wilen, 2004), the students comprehend the habit that can improve classroom discussion (Bambrick-Santoyo, 2013) and actively rising their confident to contribute in classroom discussion.

\section{Self-management}

Self-management is the following sessions where students feel necessity to conceive environmental management that able achieve their goals. The strategies that supported this session were; (a) goal setting strategy (Torrano Montalvo \& González Torres, 2004), (b) Setting up the study area (Longman \& Atkinson, 1999), (c) and help-seeking (Newman, 2008; Wolters, Pintrich, \& Karabenick, 2005).

\section{Writing strategies}

Researcher gave instruction about learning from writing are sessions where students are required to understand and take advantage of the writing process that goes on with a 
strategy that their owned. Plata (2008) state learning from writing mainly to learn the material provided by the lecturer that elaborated with the students' thought through writing (Meyer, Fisher, \& Pearl, 2007). The strategy that supported this session was; of the steps to prepare for essay writing (Burns \& Sinfield, 2012).

\section{Motivational strategies}

As the last session researcher gave learning from motivation where students are besought to comprehend the reasons which actively move them in learning process regarding for academic achievement (Pintrich, 2000). The strategies that supported this session were; (1) self-consequent, (2) mastery self-talk, (3) interest enhancement, (4) structuring the environment, (5) emotional regulation, and CRAFT method (cancel, replace, affirm, focus, train) (Gilliam, 1970).

\section{METHOD}

\section{Participant and Setting}

This research conducted in Universitas Negeri Jakarta (UNJ), Indonesia at the department of primary education (PGSD), department of special education, department. The investigation conducted on 84 undergraduate students from two classes of pedagogy faculty at department of primary education (PGSD) who enroll development of learner's course academic year 2015/2016 from class A and class C. The selection of these two groups, based on six classes (Class A-Class E) preconceived. Besides, the selection of these two classes was also due to the willingness of lecturers to collaborate in conducting this experimental research.

The following is the procedure that has been made to conduct quasi-experimental research. The researcher conducted experiments March until July 2016 by 8 times faceto-face meeting (including orientation courses).

Table 1

Intervention and Interview Schedule

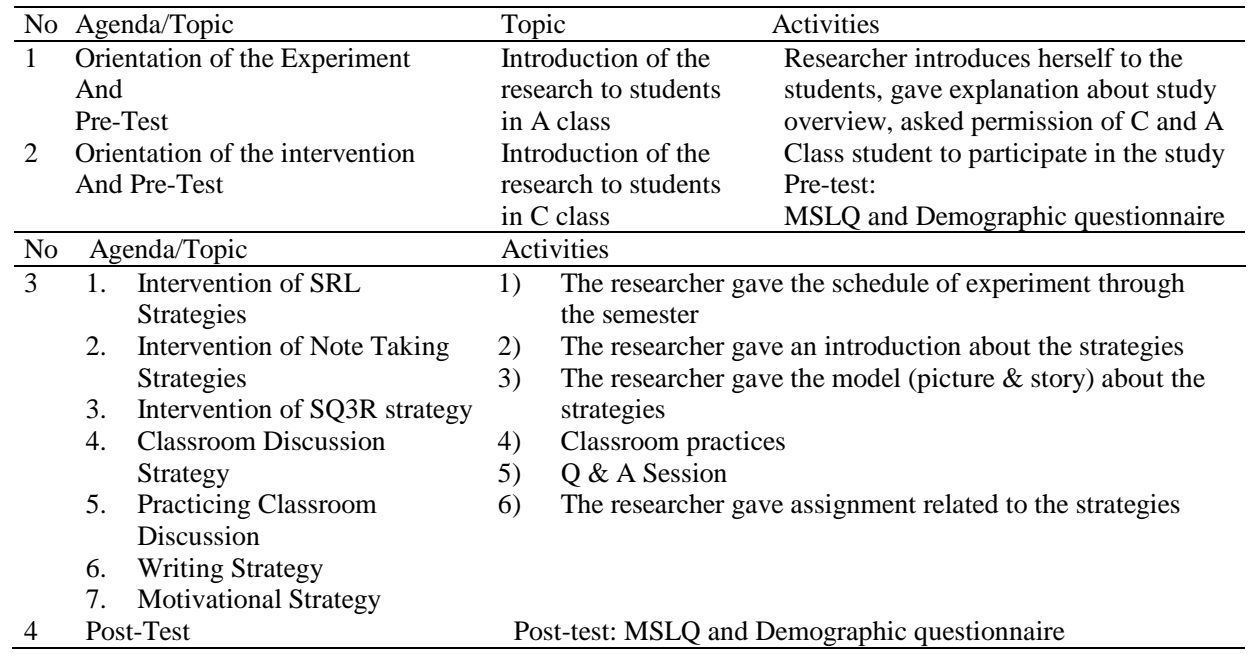




\section{Data Collection}

Testing materials that used in this experiment consist of a short demographic questionnaire also pre-test, post-test developed by Pintrich, Wolters and Karabenick (2003). Demography questionnaires helped the researcher to know general information of control and experimental group. Some of the questions include age, gender, ethnicity, academic year, GPA (see appendix A). The students' GPA was one of the researcher's considerations to select the eight interviewers.

While for the pre-test and post-test, researcher used Motivational Strategies for Learning Questionnaire (MSLQ) as a self-report instrument to inquire about the cognitive, motivational and behavioral strategies of students in learning process (Wolters et al., 2005). There were three sections that make up in this instrument: an academic cognition section, an academic motivation section and an academic behavior section, and all three have some subscales (see appendix B). The MSLQ using a seven-point Likert scale ranging from 1 (labeled "not at all true of me") to 7 (labeled "very true of me") without a special label to categorize other response (Wolters et al., 2005).

\section{Data Analysis}

The study is quasi-experimental design that used not-random assignment of participants to groups (Creswell, 2002). There are two groups who do not affect each other but their presence explains the effects of treatments given, they are experimental group is a sample that chosen to receive treatments (i.e. C-class students) while the control group (i.e. E-class students) is research participants who are not getting any intervention (Singh, 2006).

Researcher used ANCOVA to determine whether experimental and control group were not significantly different through pre-test and they were significantly different through post-test also academic achievement score (e.g. developmental psychology course). In terms of supporting the statistical analysis, researcher also used analysis of covariance 'for controlling extraneous variables and as a means of expanding the power of statistical test' (Schreiber \& Griffin, 2004). Through ANCOVA researchers adjusted the posttest scores to see the initial differences on variables (e.g. academic cognition strategies, academic motivational strategies and academic behavior strategies). The using of this procedure will also help researcher to reduce the within-group (err) variance.

The researcher used paired sample t-test to analyze the impact of SRL strategies intervention on experimental group. It used to determine pre-test and post test score of the experimental group is significantly different. Besides this paired sample t-test also used by her to know between pre-test and academic performance score is also significantly different. To test four hypotheses of this study, researcher used correlation coefficient as data analysis. It is a statistical technique that used to measuring the strength relationship between two or more variables (e.g. closely, weak or no relation) and knowing the shape relationship between two variables or more with results that are quantitative (e.g. positive linear, negative linear) (Ott \& Longnecker, 2010). On this 
analysis, researcher used Spearman rank correlation that measuring the relationship between two ordinal variables (Uyanto, 2006).

\section{FINDINGS}

The first question of the study concerned about the impact of self-regulated learning intervention to the student's academic performance. Researcher performed analysis of covariance (ANCOVA) to see the linearity between the outcome variable and the covariate also the homogeneity among groups.

The result of Lavene's test, $F(1,82)=1.152, p=.286$, indicated that the groups are equal; the relationship between the covariate and the dependent variable is the same each of these groups. The result is not violating the assumption of homogeneity of regression among groups.

Table 2

Dependent Variable: Academic Performance

\begin{tabular}{lllllllll}
\hline Source & $\begin{array}{l}\text { Type III Sum } \\
\text { of Squares }\end{array}$ & df & $\begin{array}{l}\text { Mean } \\
\text { Square }\end{array}$ & F & Sig. & $\begin{array}{l}\text { Partial } \\
\text { Squared }\end{array}$ & $\begin{array}{l}\text { Eta } \\
\text { Parameter }\end{array}$ & $\begin{array}{l}\text { Observed } \\
\text { Power }^{\mathrm{b}}\end{array}$ \\
\hline Corrected Model & $313.893^{\mathrm{a}}$ & 2 & 156.947 & 14.763 & .000 & .267 & 29.527 & .999 \\
Intercept & 3449.309 & 1 & 3449.309 & 324.464 & .000 & .800 & 324.464 & 1.000 \\
SRL_PreTest & 308.289 & 1 & 308.289 & 29.000 & .000 & .264 & 29.000 & 1.000 \\
Group & 47.197 & 1 & 47.197 & 4.440 & .038 & .052 & 4.440 & .549 \\
Error & 861.095 & 81 & 10.631 & & & & & \\
Total & 534145.000 & 84 & & & & & & \\
Corrected Total & 1174.988 & 83 & & & & & &
\end{tabular}

The ANCOVA analysis result showed from table $2, F(1,81)=4.440, p=.038$, it indicates that the two groups are significantly different from one another in terms of their outcomes variable; in this case is academic performance (i.e. Final exam). The effect size is .052 which is indication of magnitude of the effect. The differences going to be present in the population in that large of $5.2 \%$ partial eta squared which is very small. The influence of the covariate showed on the pre-test value, $F(1,81)=29.00, p=$ .000 , it indicated that the covariate is a significant effect on the outcome. The result showed that the .264 partial eta-squared; it explained that covariate affected about 26.4 $\%$ of the academic performance.

The analysis for the second question of the study concerned about the impact of selfregulated learning intervention to the student's post-test. Researcher performed an analysis of covariance (ANCOVA) in terms to see the linearity and the homogeneity relationship between the corporate and dependent variable. 
Table 3

Analysis Covariance (Post-test)

\begin{tabular}{|c|c|c|c|c|c|c|c|c|}
\hline Source & $\begin{array}{l}\text { Type III Sum of } \\
\text { Squares }\end{array}$ & df & $\begin{array}{l}\text { Mean } \\
\text { Square }\end{array}$ & $\mathrm{F}$ & Sig. & $\begin{array}{l}\text { Partial Eta } \\
\text { Squared }\end{array}$ & $\begin{array}{l}\text { Noncent. } \\
\text { Parameter }\end{array}$ & $\begin{array}{l}\text { Observed } \\
\text { Power }^{b}\end{array}$ \\
\hline $\begin{array}{l}\text { Corrected } \\
\text { Model }\end{array}$ & $66150.236^{\mathrm{a}}$ & 2 & 33075.118 & 12.043 & .000 & .229 & 24.086 & .994 \\
\hline Intercept & 66822.828 & 1 & 66822.828 & 24.331 & .000 & .231 & 24.331 & .998 \\
\hline SRL_PreTest & 62419.865 & 1 & 62419.865 & 22.728 & .000 & .219 & 22.728 & .997 \\
\hline Group & 39.459 & 1 & 39.459 & .014 & .905 & .000 & .014 & .052 \\
\hline Error & 222456.717 & 81 & 2746.379 & & & & & \\
\hline Total & 23867250.000 & 84 & & & & & & \\
\hline $\begin{array}{l}\text { Corrected } \\
\text { Total }\end{array}$ & 288606.952 & 83 & & & & & & \\
\hline
\end{tabular}

The ANCOVA analysis result showed from table $5, F(1,81)=0.14, \mathrm{p}=.905$, it indicates that the two groups are not significantly different from one another in terms of their outcomes variable; in this case is academic performance (i.e. Final exam). The effect size is .000 which is indication of magnitude of the effect. The presentation equation in the population is $0.000008 \%$ partial eta squared, which is very small. The influence of the covariate showed on the pre-test value, $F(1,81)=22.728, p=.000$, it indicated that the culvert is a significant effect on the outcome. The result showed that the .219 partial eta-squared; it explained that covariate affected about $21.9 \%$ of the post-test.

The correlation coefficient (i.e. Spearman rank correlation) performed by researcher to answer the third research questions. The Descriptive analysis of three variables is; academic cognition $(M=128.88, S D=17.608, n=43)$, academic motivation $(M=196.07$, $S D=24.801, n=43)$ and academic behavior $(M=214.35, S D=20.134, n=43)$.

Table 4

Correlation Analysis of SRL Variable (Post-test)

\begin{tabular}{|c|c|c|c|c|c|}
\hline & & & $\begin{array}{l}\text { Academic } \\
\text { Cognition }\end{array}$ & $\begin{array}{l}\text { Academic } \\
\text { Motivation }\end{array}$ & $\begin{array}{l}\text { Academic } \\
\text { Behavior }\end{array}$ \\
\hline \multirow[t]{9}{*}{$\begin{array}{l}\text { Spearman's } \\
\text { rho }\end{array}$} & \multirow[t]{3}{*}{$\begin{array}{l}\text { Academic } \\
\text { Cognition }\end{array}$} & $\begin{array}{l}\text { Correlation } \\
\text { Coefficient }\end{array}$ & 1.000 & $.660^{* *}$ & $.566^{* *}$ \\
\hline & & Sig. (2-tailed) & . & .000 & .000 \\
\hline & & $\mathrm{N}$ & 43 & 43 & 43 \\
\hline & \multirow[t]{3}{*}{$\begin{array}{l}\text { Academic } \\
\text { Motivation }\end{array}$} & $\begin{array}{l}\text { Correlation } \\
\text { Coefficient }\end{array}$ & $.660^{* * *}$ & 1.000 & $.409^{* *}$ \\
\hline & & Sig. (2-tailed) & .000 & & .006 \\
\hline & & $\mathrm{N}$ & 43 & 43 & 43 \\
\hline & \multirow[t]{3}{*}{$\begin{array}{l}\text { Academic } \\
\text { Behavior }\end{array}$} & $\begin{array}{l}\text { Correlation } \\
\text { Coefficient }\end{array}$ & $.566^{* * *}$ & $.409^{* * *}$ & 1.000 \\
\hline & & Sig. (2-tailed) & .000 & .006 & . \\
\hline & & $\mathrm{N}$ & 43 & 43 & 43 \\
\hline
\end{tabular}

**. Correlation is significant at the 0.01 level (2-tailed).

The correlation coefficient analysis result showed from table 4, that the three variables are significantly correlated. The academic cognition and academic motivation have 
correlation statically significant $(p=.000, R=.660)$, it explained that academic cognition correlated about $66.0 \%$ to academic motivation. Academic cognition and academic behavior have significant correlated ( $p=.000, R=.566)$, it means that academic cognition correlated about $56.6 \%$ to academic behavior. Academic motivation and academic behavior has correlation statically significant $(p=.00, R=.409)$, it defined that academic motivation correlated about $40.9 \%$ to academic behavior.

Table 5

Paired Sample Statistics of SRL Variables (Experimental Group)

\begin{tabular}{llllll}
\hline & & Mean & N & Std. Deviation & Std. Error Mean \\
\hline Pair 1 & Academic Cognition_1 & 125.49 & 43 & 22.240 & 3.392 \\
& Academic Cognition & 112.88 & 43 & 17.608 & 2.685 \\
Pair 2 & Academic Motivation_1 & 192.35 & 43 & 28.456 & 4.340 \\
& Academic Motivation & 196.07 & 43 & 24.801 & 3.782 \\
Pair 3 & Academic Behavior_1 & 213.02 & 43 & 23.088 & 3.521 \\
& Academic Behavior & 214.35 & 43 & 20.134 & 3.070 \\
\hline
\end{tabular}

In terms of test the fourth hypotheses and supporting correlation coefficient analysis result, the researcher performed an analysis of paired sample t-test to see the impact of intervention for experimental group regarding their pre-test and post-test result among three variables of SRL. The paired sample statistic result of academic cognition variables were not significantly different after intervention; the pre-test result $(M=125.49, S D=22.240)$ and post-test result $(M=112.88, S D=17.608)$. The paired sample statistic result of academic motivation variables was significantly different after intervention; the pre-test result $(M=192.35, S D=28.456)$ and post-test result $(M=196.07$, $S D=24.801$ ), the differences were $M=3.721$. The paired sample statistic result of academic behavior variables was significantly different after intervention; the pre-test result $(M=213.02, S D=23.088)$ and post-test result $(M=214.35, S D=20.134)$, the differences were $M=1.326$.

\section{DISCUSSION}

The ANCOVA result showed the groups are significantly different from one to another in terms of their outcomes about 5.2\%. The influenced of the pre-test to the academic performance about $26.4 \%$, it indicated that $73.6 \%$ the outcomes influence by the SRL strategies intervention. It can be concluded that the SRL strategies intervention has positively impacted on students' self-regulated learning and academic performance. In other words, the concept of self-regulated learning may predict academic success, and vice versa, academic success may predict the concept of self-regulated learning (Bozpolat, 2016; Senler \& Sungur-Vural, 2014). There are many studies that showed similar results that self-regulation strategies are factors that affect academic success. The study by Banarjee \& Kumar (2014) revealed that there is positively significant relationship between self-regulated learning with academic achievement among science graduate students. The study by Suk, Hwang, and Vrongistinos (2002) involving elementary in-service teacher's students determined a positive relationship between selfregulated learning and success in an Educational Psychology course. The research by Tsai, Lee \& Shen (2013) involving private vocational school students determined a 
positive relationship between combine intervention of PBL (Problem Based Learning) and SRL with students' scores of computing skills. San (2016) concluded in his study that self-regulated learning used in chemistry class were a significant predictor of the academic success in chemistry class. The study by Bruso \& Stefaniak (2016) involving college students determined self-regulated learning has a positive relationship as predictor of academic success in distance learning.

The second hypothesis showed undergraduate students who receive self-regulated learning strategies intervention would display greater of self-regulated learning (e.g. post-test result).The result of ANCOVA revealed that the groups are not significantly different from one to another in terms of their post-test, but the presentation of the equation is very small about $0.000008 \%$. Even the post-test results of these two groups are equal, but the descriptive analysis displayed there were a greater result of experimental group's post-test $(M=534.44, S D=61.67)$ compares to the pre-test $(M=542.67, S D=54.75)$. This characteristic was in accordance with earlier study by educational researchers (Andrzejewski et al., 2016; Bozpolat, 2016; Gu \& Lee, 2019; Lehmann et al., 2014; Vandevelde et al., 2011) which found that the self-regulated learning variables has significant difference between pre-test and post-test result. It means that students increasingly master the SRL strategy after the intervention is given. In addition this shows that mastery of this strategy can be internalized in an academic setting.

The third hypothesis showed there were significant correlations among SRL variables (e.g. Academic cognition, academic motivation and academic behavior strategies). The result of correlation coefficient analysis of experimental group's post-test score displayed that those three variable are significantly correlated. This finding was in line with the previous research ((Bozpolat, 2016; Vandevelde et al., 2011) who discovered that academic motivation variables were correlated with academic cognition and behavior. It also has an impact to the increasing of academic cognition and behavioral variable scores. As well as the study conducted by Dörrenbächer \& Perels (2016) involving college students determine that the students that high SRL scores has high resulted in their academic motivational variable scores.

The fourth hypotheses showed significantly different on post-test of SRL variables in the experimental group. It can be concluded that the result of paired sample t-test determined intervention given by researcher has improved. The post-test result of experimental group; academic cognition $(M=12.605)$, academic motivation $(M=$ $3.721)$ academic behavior $(M=-1.326)$ has increased compared with the pre-test result. The result of hypothesis fourth was in line with the study that Yakar et al. (2013) conducted on teacher education program for 240 science pre-service teachers. They found that experimental research of SRL strategies intervention could develop students' motivational orientation (i.e. Intrinsic goal orientation, task value, control of learning beliefs, self-efficacy for learning and performance) and learning strategy (i.e. Elaboration, critical thinking, meta-cognitive self-regulation, time and study environment management and peer learning). 


\section{CONCLUSION AND RECOMENDATION}

The findings showed that the SRL strategies intervention is a constructive program which more effective than the traditional one. It had designed to increase students' cognitive, meta-cognitive, behavioral, motivational and contextual skill. The researcher also believed that these SRL skills would not only help the students to realize the important to be a good quality prospective teacher, but also made them motivate to master the SRL skill as a way to achieve better academic performance. The researcher believed if the Teacher Education structured Institution open more opportunity to the student teachers learn and apply SRL skill on a program through four-year undergraduate program, this institution would produce a good quality of prospective teachers.

The researcher concluded the instruments of SRL intervention based on the Pintrich Model made her comprehend the students' proceed to regulate themselves in learning through the SRL dimension and phases. The SRL intervention and the instruments support also lets students' has been realized, comprehended and able to use all strategies in their learning process. They acknowledged the SRL strategies intervention make them more regulated themselves to plan, monitor, control and reflect/future action their academic performance. Moreover, they are sophomore students who have little knowledge and experience how is learning activities on campus. The SRL strategies intervention that they received would be a direction for them to face academic and difficulties problems for now and future.

This study has several implications for future research has well as to educational practice. First, regarding the relations between SRL strategies intervention and academic accomplishments, it would be interesting to do longitudinal studies that allow causal inference. Future research that will contribute more information sustainability of students' self-regulated learning. Second, future research should examine comparative studies base on the differences of educational stages, courses, faculty and department, high and low achieving students, and the students who have special needs. Third, this research was introduced some SRL strategies to the students in general. To have different insight and result the future research can do experimental research which focuses only one strategy and discussed in-depth. So the researcher will gain rich data and its implication of that strategy to the students in learning process and their academic achievement. Fourth implication of this study is recommend to Teacher Education Institution to provide a conjunct course of self-regulated learning strategies development (Simpson, Hynd, Nist, \& Burrell, 1997) or make the teacher education program structured for undergraduate students (e.g. Sophomore). The making of the program becomes structured let the students as a learner became aware of their own learning and give them the opportunity to use meta-cognitive strategies. The last implication need to be supported by the lecture in Teacher Education Institution as a major role to make the students be self-motivated in the learning process. That means lecturer needs to give more attention to enhance students' self-regulated learning while teaching, by giving explicit self-regulated learning strategies practice/course or integrate the theory with their teaching material or courses. Because to exercise optimal self-regulated learning, 
student require opportunities for being reflected and for accommodating knowledge and experiences (Simpson et al., 1997).

\section{REFERENCES}

Ahonen, E., Pyhältö, K., Pietarinen, J., \& Soini, T. (2014). Teachers' professional beliefs about their roles and the pupils' roles in the school. Teacher Development, 18(2), 177-197.

Alvi, E., \& Gillies, R. M. (2015). Social interactions that support students' selfregulated learning: A case study of one teacher's experiences. International Journal of Educational Research, 72, 14-25.

Andrzejewski, C. E., Davis, H. A., Bruening, P. S., \& Poirier, R. R. (2016). Can a selfregulated strategy intervention close the achievement gap? Exploring a classroom-based intervention in 9th grade earth science. Learning and Individual Differences, 49, 85-99.

Bambrick-Santoyo, P. (2013). Habits improve classroom discussions. Phi Delta Kappan, 95(1), 70-71.

Boekaerts, M., \& Corno, L. (2005). Self-regulation in the classroom: A perspective on assessment and intervention. Applied Psychology, 54(2), 199-231.

Bozpolat, E. (2016). Investigation of the self-regulated learning strategies of students from the faculty of education using ordinal logistic regression analysis. Educational Sciences: Theory and Practice, 16(1), 301-318.

Burns, T., \& Sinfield, S. (2012). Essential study skills: The complete guide to success at university. Sage.

Castro, A. J. (2014). The role of teacher education in preparing teachers for critical multicultural citizenship. The Journal of Social Studies Research, 38(4), 189-203.

Creswell, J. W. (2002). Educational research: Planning, conducting, and evaluating quantitative. Upper Saddle River, NJ: Prentice Hall.

Crossley, M., Koya Vaka’uta, C. F., Lagi, R., McGrath, S., Thaman, K. H., \& Waqailiti, L. (2017). Quality education and the role of the teacher in Fiji: mobilising global and local values. Compare: A Journal of Comparative and International Education, 47(6), 872-890.

Dar, F. R. (2015). Rethinking education--emerging roles for teachers. Universal Journal of Educational Research, 3(2), 63-74.

Denzler, S., \& Wolter, S. C. (2009). Sorting into teacher education: How the institutional setting matters. Cambridge Journal of Education, 39(4), 423-441.

Deslauriers, L., Harris, S. E., Lane, E., \& Wieman, C. E. (2012). Transforming the lowest-performing students: an intervention that worked. Journal of College Science Teaching, 41(6), 80-88. 
Dörrenbächer, L., \& Perels, F. (2016). Self-regulated learning profiles in college students: Their relationship to achievement, personality, and the effectiveness of an intervention to foster self-regulated learning. Learning and Individual Differences, 51, 229-241.

Farley, J. P., \& Kim-Spoon, J. (2014). The development of adolescent self-regulation: Reviewing the role of parent, peer, friend, and romantic relationships. Journal of Adolescence, 37(4), 433-440.

Feldt, R. C., \& Hensley, R. (2009). Recommendations for use of SQ3R in introductory psychology textbooks. Education, 129(4), 584-589.

Gestsdóttir, S., Urban, J. B., Bowers, E. P., Lerner, J. V., \& Lerner, R. M. (2011). Intentional self-regulation, ecological assets, and thriving in adolescence: $\mathrm{A}$ developmental systems model. New Directions for Child and Adolescent Development, 2011(133), 61-76.

Gilliam, L. (1970). Synthetic confrontation therapy. Research in Education, 5, 1-12.

Gu, P., \& Lee, Y. (2019). Promoting students' motivation and use of SRL strategies in the web-based mathematics learning environment. J of Edu Tec Sys, 47(3), 391-410.

Heller, M. L., \& Marchant, G. J. (2015). Facilitating self-regulated learning skills and achievement with a strategic content learning approach. Community College Journal of Research and Practice, 39(9), 808-818.

Hofer, B. K., \& Yu, S. L. (2003). Teaching self-regulated learning through a" Learning to Learn" course. Teaching of Psychology, 30(1), 30-33.

Hofer, B. K., Yu, S. L., \& Pintrich, P. R. (1998). Teaching college students to be selfregulated learners. In D. H. Schunk, \& B. J. Zimmerman (Eds.), Self-regulated learning: From teaching to self-reflective practice (p. 57-85). Guilford Publications.

Kramarski, B., \& Michalsky, T. (2010). Preparing preservice teachers for self-regulated learning in the context of technological pedagogical content knowledge. Learning and Instruction, 20(5), 434-447.

Lehmann, T., Hähnlein, I., \& Ifenthaler, D. (2014). Cognitive, metacognitive and motivational perspectives on preflection in self-regulated online learning. Computers in Human Behavior, 32, 313-323.

Longman, D. G., \& Atkinson, R. H. (1999). Study methods and reading technique. Belmont, CA: Wadsworth.

Markovits, H., Doyon, C., \& Simoneau, M. (2002). Individual differences in working memory and conditional reasoning with concrete and abstract content. Thinking \& Reasoning, 8(2), 97-107.

Meyer, J. A., Fisher, B. J., \& Pearl, P. S. (2007). Students' perceptions of the value of a self-study writing assignment. Journal of Instructional Psychology, 34(4), 234. 
Newman, R. S. (2008). Adaptive and nonadaptive help seeking with peer harassment: An integrative perspective of coping and self-regulation. Educational Psychologist, 43(1), 1-15.

Ott, L., \& Longnecker, M. (2010). An introduction to statistical methods and data analysis. Australia Brooks: Cole Cangage Learning.

Paris, S. G., Byrnes, J. P., \& Paris, A. H. (2001). Constructing theories, identities, and actions of self-regulated learners. In B. J. Zimmerman, \& D. H. Schunk (Eds.), Selfregulated learning and academic achievement: Theoretical perspectives (p. 253-287). Lawrence Erlbaum Associates Publishers..

Perels, F., Merget-Kullmann, M., Wende, M., Schmitz, B., \& Buchbinder, C. (2009). Improving self-regulated learning of preschool children: Evaluation of training for kindergarten teachers. British Journal of Educational Psychology, 79(2), 311-327.

Pintrich, P. R. (2000). The role of goal orientation in self-regulated learning. In M. Boekaerts, P. R. Pintrich, \& M. Zeidner (Eds.), Handbook of self-regulation (pp. 451502): Elsevier.

Piolat, A., Olive, T., \& Kellogg, R. T. (2005). Cognitive effort during note taking. Applied cognitive psychology, 19(3), 291-312.

Prakash, S., \& Xavier, S. (2014). Role of teacher educational institutions in developing personality of student teachers. Journal on Educational Psychology, 8(1), 37-41.

Rissanen, I., Kuusisto, E., Hanhimäki, E., \& Tirri, K. (2018). The implications of teachers' implicit theories for moral education: A case study from Finland. Journal of Moral Education, 47(1), 63-77.

Schreiber, J. B., \& Griffin, B. W. (2004). Review of multilevel modeling and multilevel studies in the journal of educational research (1992-2002). The Journal of Educational Research, 98(1), 24-34.

Schwartz, S. S. (2012). Self-regulation, motivational conflict, and values. College of Saint Elizabeth.

Senler, B., \& Sungur-Vural, S. (2014). Pre-service science teachers' use of selfregulation strategies. Procedia-Social and Behavioral Sciences, 152, 551-556.

Simpson, M. L., Hynd, C. R., Nist, S. L., \& Burrell, K. I. (1997). College academic assistance programs and practices. Educational Psychology Review, 9(1), 39-87.

Singh, Y. K. (2006). Fundamental of research methodology and statistics. New Age International.

Tantrarungroj, P., \& Suwannatthachote, P. (2013). Enhancing pre-service teacher's selfefficacy and technological pedagogical content knowledge in designing digital media with self-regulated learning instructional support in online project-based learning. Creative Education, 3(08), 77. 
Torrano Montalvo, F., \& González Torres, M. (2004). Self-regulated learning: Current and future directions. J. de la Fuente, \& M. A. Eissa (Eds.), International handbook on applying self-regulated learning in different settings (pp. 27-50). Education \& Psychology.

Uyanto, S. S. (2006). Guidelines for data analysis with SPSS. Yogyakarta: Graha Ilmu.

van der Meer, J. (2012). Students' note-taking challenges in the twenty-first century: Considerations for teachers and academic staff developers. Teaching in higher education, 17(1), 13-23.

Vandevelde, S., Van Keer, H., \& De Wever, B. (2011). Exploring the impact of student tutoring on at-risk fifth and sixth graders' self-regulated learning. Learning and Individual Differences, 21(4), 419-425.

Vrieling, E. M., Bastiaens, T. J., \& Stijnen, S. (2012). Effects of increased self-regulated learning opportunities on student teachers' metacognitive and motivational development. International journal of educational research, 53, 251-263.

Weinstein, C. E., Ridley, D. S., Dahl, T., \& Weber, E. S. (1989). Helping students develop strategies for effective learning. Educational Leadership, 46(4), 17-19.

Wilen, W. W. (2004). Refuting misconceptions about classroom discussion. The Social Studies, 95(1), 33-39.

Wolters, C. A., Pintrich, P. R., \& Karabenick, S. A. (2005). Assessing academic selfregulated learning. In K. A. Moore, \& L. H. Lippman (Eds.), The search institute series on developmentally attentive community and society. What do children need to flourish: Conceptualizing and measuring indicators of positive development (p. 251-270). Springer Science + Business Media. https://doi.org/10.1007/0-387-23823-9_16.

Yakar, Z., Can, B., \& Besler, H. (2013). Does the teaching program effect on preservice teacher's self-regulation? Int Journal of Academic Research, 5(3), 93-101.

Yusri, G., Rahimi, N. M., Shah, P. M., \& Wah, W. H. (2013). Cognitive and metacognitive learning strategies among Arabic language students. Interactive Learning Environments, 21(3), 290-300.

Zimmerman, B. J. (1998). Developing self-fulfilling cycles of academic regulation: An analysis of exemplary instructional models. In D. H. Schunk, \& B. J. Zimmerman (Eds.), Self-regulated learning: From teaching to self-reflective practice (p. 1-19). Guilford Publications.

Zimmerman, B. J. (2008). Investigating self-regulation and motivation: Historical background, methodological developments, and future prospects. American educational Research Journal, 45(1), 166-183. 